Article

\title{
Exploring the Potential and Contribution of UNESCO Biosphere Reserves for Landscape Governance and Management in Africa
}

\author{
Bettina Hedden-Dunkhorst ${ }^{1, *}$ and Florian Schmitt ${ }^{2}$ \\ 1 Federal Agency for Nature Conservation, Konstantinstr. 110, 53179 Bonn, Germany \\ 2 German Commission for UNESCO, Martin-Luther-Allee 42, 53175 Bonn, Germany; Schmitt@unesco.de \\ * Correspondence: Bettina.Hedden-Dunkhorst@bfn.de
}

Received: 23 June 2020; Accepted: 17 July 2020; Published: 22 July 2020

\begin{abstract}
United Nations Educational Scientific and Cultural Organization (UNESCO) Biosphere Reserves strive for a harmonious interaction between humans and nature. As landscapes provide suitable units to mutually address matters of conservation and sustainable development, this study aims to explore the potential and realized contribution of biosphere reserves for landscape governance and management. We emphasize the role of stakeholder participation and cooperation as an overarching condition for integrated landscape approaches. The regional focus is on Africa, where multiple drivers of global and local change currently significantly impact the landscape. The study's results are based on a literature review, which is complemented by four case studies from the biosphere reserves in Ghana, Malawi, South Africa, and Benin/Togo. Findings show that in biosphere reserves, stakeholder engagement is crucial to gain community acceptance, foster intersectoral cooperation, and provide management with more legitimacy. To strengthen stakeholders' capacities to mutually achieve conservation and development outcomes, international partnerships and research and education efforts proved to be successful. The flexible biosphere reserve approach to governance, which allows for integration with other land-management approaches, offers a suitable governance model for a landscape. Moreover, the biosphere reserve zonation concept can provide orientation to manage the "multifunctionality" of a landscape and address the associated trade-offs between different stakeholders' aspirations.
\end{abstract}

Keywords: landscapes; biosphere reserves; stakeholder participation; conservation; sustainable development; governance; management; communication; capacity building

\section{Introduction}

Landscapes ${ }^{1}$ transform over time as land use changes, infrastructure develops, human populations fluctuate, and impactful natural events occur. Ideally, landscape governance and management will adapt to these changing conditions to safeguard ecosystem functionality and guarantee sustainability. However, in large parts of the world, landscapes have been modified such that their carrying capacities have been exceeded, and irreversible environmental degradation ensued [5]. This situation often coincides with severe conflicts over natural resources that affect peoples' livelihoods and security [6]. Accordingly, over the last few decades, the need to balance human-induced developments and

1 The term landscape is used by several scientific disciplines drawing on a wide range of definitions and concepts [1,2]. Considering a number of definitions developed more recently by various authors [1-4], we understand landscapes as dynamic, interactively developing social-ecological systems that often combine a mosaic of alternative land uses and different governance structures. 
environmental resilience became increasingly obvious [7], with landscapes considered to be a suitable spatial unit for the governance and management of social-ecological systems [8,9].

To address and resolve the conflicts among different interest groups in a specific landscape, stakeholder participation, engagement, and collaboration is increasingly considered to be a major decisive factor $[3,10]$. In a landscape framework that includes operational governance structures and functioning institutions, stakeholder engagement is an important element to successfully negotiate inevitable trade-offs as part of conflict resolution [3,10-12]. However, as landscape institutions interact with superior levels of governance structures or ecological systems and the stakeholder spectrum expands, complexity and interdependences also grow further [1].

In this context, the concept of biosphere reserves and its implementation-conceptualized by the United Nations Educational Scientific and Cultural Organization's (UNESCO) science program "Man and the Biosphere" (MAB) and globally implemented since 1976 [13]—may offer valuable insights and experiences for landscape governance and management that focus on environmentally balanced sustainable development. As biosphere reserves are "designed to combine biodiversity conservation with socio-economic development and knowledge production (both scientific and local) and dissemination" [9], this concept proposes to address actual and future landscape challenges. Today, 701 biosphere reserves have been designated by UNESCO in 124 countries; together, they form the World Network of Biosphere Reserves (WNBR) [14]. Within its regional or thematic sub-networks (e.g., AfriMAB, the network of biosphere reserves in Sub-Saharan Africa), the WNBR promotes the sharing of best practices and experiences from biosphere reserves around the world [15]. Each biosphere reserve designation precedes a stakeholder participation process and a formal request by the respective national government. Biosphere reserves are areas of different sizes and focuses, but they often emphasize one ecosystem type or natural or cultural landscape.

This study aims to explore the potential and realized contribution of UNESCO's biosphere reserve concept and its implementation to landscape governance and management in Africa. Its objective is to provide a common understanding of biosphere reserve structures, functions, and processes and to illustrate their relevance for landscape approaches based on four case studies. According to our knowledge, investigating biosphere reserves in Africa from a landscape perspective is somewhat novel. The majority of references investigate biosphere reserves from an intrinsic perspective, while only a few studies [16] take a broader perspective and analyze biosphere reserves as implementing units for landscape governance and management. The focus of the present study is on key components of a landscape approach, as obtained from a review of the literature. The case study findings are reported in the form of narratives to complement the literature review and to illustrate first-hand practical experiences. The motivation for this study is derived from the notion that different landscape concepts and approaches, which have emerged over time in various situations, can build upon and complement each other [7,12]. Thus, alternative approaches to natural resource management that aim to link conservation with sustainable development in Africa are likewise taken into consideration and contrasted. The focus of this study is on Africa, where multiple drivers of global and local change currently significantly impact landscapes [4]. At the same time, the implementation of the MAB program has made progress in parts of the continent, with the goal to establish model regions for sustainable development.

In this context, the overall guiding question of the study is the following: what can we learn from the concept of biosphere reserves and their implementation for landscape governance and management in Africa? We hypothesize that biosphere reserves: (1) provide a structural framework for landscape governance and management and foster links between different hierarchies; (2) coordinate intersectoral activities to achieve mutual conservation and sustainable development objectives in the designated area; (3) provide opportunities for knowledge generation and learning for stakeholders; and (4) address trade-offs between nature and people in a holistic manner, while contributing to conflict resolution among different interest groups. This study focuses on stakeholder engagement and collaboration, assuming these to be overarching conditions for the development and maintenance of governance 
and management structures and the implementation of programs and projects to achieve sustainable development targets.

The following section describes the concept of biosphere reserves, as well as alternative landscape approaches, in Africa. Section 3 depicts the methods applied in the study and outlines an analytical framework that identifies four crucial components for integrated approaches to landscapes. Through this analytical lens, the results from a literature review are presented in Section 4 to analyze the biosphere reserve concept considering the four components. The analysis is complemented by findings from four case studies of biosphere reserves located in western and southern Africa and a discussion of factors that may impact success and failure in different contexts. In Section 5, we relate the results of the analysis of biosphere reserves to the wider discussion on conservation and development in African landscapes and draw lessons learnt from the investigation of biosphere reserves as potential models for landscape governance and management. The final section draws some general conclusions of the study.

\section{The Concept of Biosphere Reserves and Alternative Landscape Approaches in Africa}

\subsection{United Nations Educational Scientific and Cultural Organization (UNESCO) Biosphere Reserves}

Biosphere reserves are the primary tool of UNESCO's MAB program. This program was established in 1971 to strengthen the research on and implementation of human interactions with ecosystems and to explore conservation strategies that facilitate the sustainable use of natural resources and ecosystem services [17]. According to UNESCO's definition, biosphere reserves are "learning places for sustainable development. They are sites for testing interdisciplinary approaches to understanding and managing changes and interactions between social and ecological systems, including conflict prevention and management of biodiversity. They are places that provide local solutions to global challenges" [18].

The concept of biosphere reserves has been adapted continuously since its establishment [19]. Initially, areas were mainly designated based on biodiversity criteria and their capacity to support research activities [11]. In 1995, the MAB program's "Seville Strategy and the Statutory Framework of the WNBR" was adopted. This strategy identifies the specific role of biosphere reserves in developing a new vision of the relationship between conservation and development. It further stresses the need for sustainable development, participatory landscape governance, and management and the role of biosphere reserves to provide interactions between society and ecosystems through dialogue among relevant actors [20]. Thus, biosphere reserves presently serve as "model regions for sustainable development" [21] worldwide [9,10], aiming to integrate conservation with the improvement of local livelihood. To realize this vision, biosphere reserves concurrently aim to achieve the following three complementary functions:

1. Conservation: to protect and conserve genetic resources, species, ecosystems, and landscapes;

2. Development: to foster sustainable economic and human development;

3. Logistic support: to support demonstration projects, environmental education and training, and research and monitoring related to local, national, and global issues of conservation and sustainable development [20].

Biosphere reserves are designated by an intergovernmental body, the MAB International Coordinating Council (MAB ICC). The designation process follows a common set of globally agreed-upon rules and principles. The designated area remains fully under national jurisdiction, however, according to the Statutory Framework of the WNBR, an integrated governance framework and management plan is obligatory for a biosphere reserve [20]. The nomination process involves a profound understanding of the bio-geographic and socio-economic situation of the area but also demands the development of a clear strategy on how to fulfill the three functions of the biosphere reserve and the engagement of major local stakeholders. Eventually, the nomination dossier requires 
the formal acceptance of all relevant authorities and political representatives at different governance levels (local, provincial, and national), before it can be submitted to UNESCO by the responsible national authority [20].

\section{Characteristic Tools and Features of Biosphere Reserves}

A characteristic tool to pursue the three functions of a biosphere reserves is the zonation concept. A biosphere reserve is zoned into one or more "core areas", a "buffer zone" surrounding the core areas, and a "transition area" (see Figure 1). A core area represents a legally protected site for the conservation of biodiversity and limits activities beyond conservation to research and education only. Some form of national or local legal protection of the core zone(s) is the only condition prescribed by the MAB program in terms of zonation. Hence, biosphere reserves have one or more legally protected core area(s), while their respective buffer zone(s) and surrounding transition zones have limited (or non-existent) legal protection status [22]. Many biosphere reserves integrate pre-existing protected sites as core areas and connect them through buffer zones forming "ecological corridors" [23]. The buffer zone is used for ecologically sound practices, e.g., for farming or tourism. The transition zone denotes an area with a variety of activities (including economic activities from subsistence crop and livestock farming to commercial agriculture, trade, industry, and tourism), where multiple stakeholders cooperate to manage and sustainably develop the area's resources [20]. Examples across the world show that biosphere reserves indeed have the potential to foster local economic development by generating additional income and employment opportunities associated with different economic sectors [22,24,25]. Specifically, the development of new technologies related to the sustainable use of land and water resources and the use of renewable energy or institutional innovations (like smallholder co-operatives or conservation associations) provide the potential to stimulate employment $[16,22,26]$.

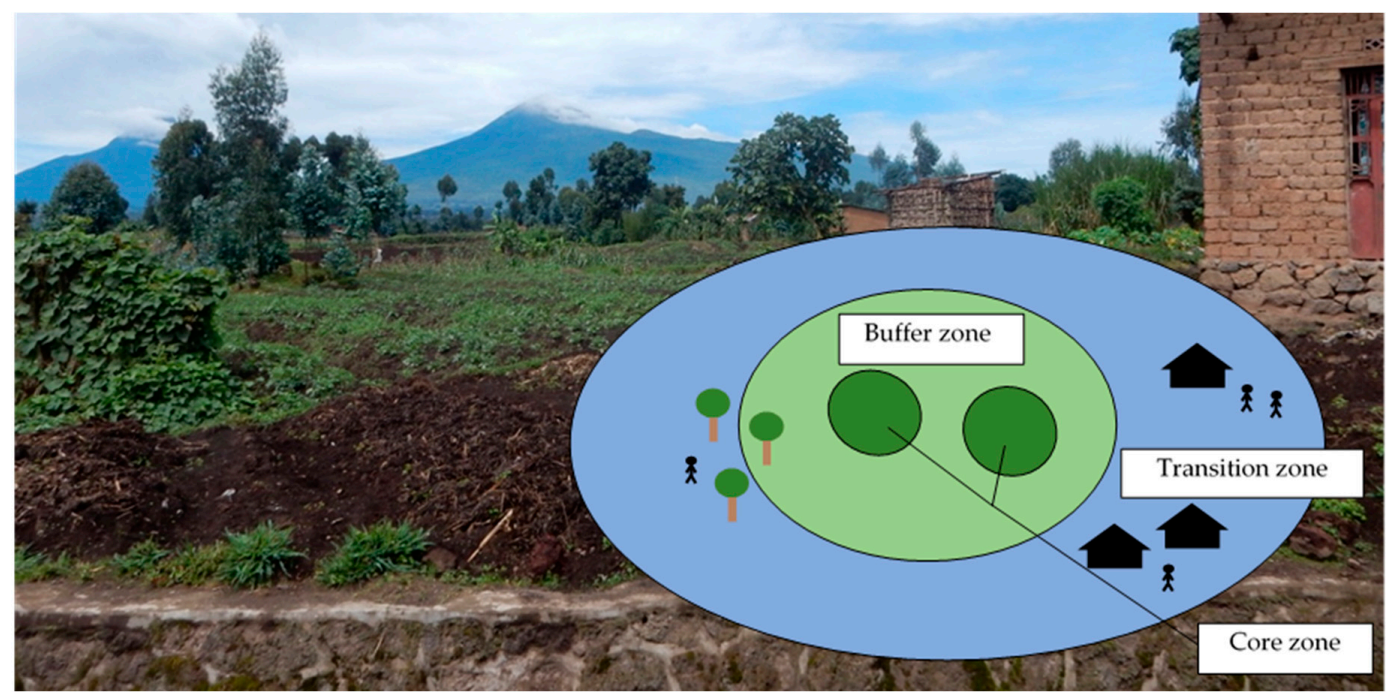

Figure 1. The zonation concept of the United Nations Educational Scientific and Cultural Organization (UNESCO) Biosphere Reserves; picture: Volcans Biosphere Reserve, Rwanda, with the volcanoes being the core zone; compiled by the authors.

In recent decades, UNESCO Biosphere Reserves have contributed to raising awareness of the need for global standards to integrate conservation with social and economic development. Today, other national and international designations of protected areas follow the notion of zonation and likewise interlink conservation and local development [27]. UNESCO Biosphere Reserves, however, accentuate their priorities differently compared to most other categories of protected areas, as their primary goal is the harmonization of the human-nature relationship within the designated area $[9,28]$. 
It is mandatory that the core zone of a biosphere reserve be a protected site under national or sub-national law. Hence, in most cases, biosphere reserves integrate pre-existing protected areas. Depending on the local and national importance of the protected area, this situation can substantially impact the landscape and its governance and management system.

The designation of a specific area as a UNESCO Biosphere Reserve also has the potential to further strengthen existing conservation activities, specifically by linking these activities to developments beyond the boundaries of the actual protected area and by providing a supportive and integrated institutional frame [16]. However, encompassing conservation sites under other formal arrangements (e.g., National Parks) within a biosphere reserve also bears the risk that a biosphere reserve will fail to achieve its potential as an "open concept" that links conservation and development due to disagreements, a lack of support, and conflicts among local stakeholders [9].

To ensure the long-term quality of designated sites, the Statutory Framework of the WNBR entails a 10-year-periodic review process to monitor, assess, and report on developments within a biosphere reserve. The results of this reporting process were mixed during the first two decades of its implementation [19]. However, since 2013, the MAB ICC has introduced several additional measures to further ensure the quality of the WNBR. These include an "excellence process" to support mechanisms for biosphere reserves that do not fully conform with the standards of the WNBR, as well as an "exit strategy" for Biosphere Reserves that remain non-compliant with UNESCO's designation criteria [9,29].

An important feature that determines the success of a biosphere reserve in achieving its goals is local ownership through identification of local stakeholders with the vision and mission of a biosphere reserve [23,30,31]. UNESCO Biosphere Reserves are characterized by involving local communities and interested stakeholders in the decision-making processes and implementation of effective benefit-sharing mechanisms [16]. Such inclusive engagement can reduce conflicts of interest and generate economic opportunities for the local population and the likelihood for development-oriented approaches to achieve successful outcomes [11].

\subsection{Alternative Natural Resource Management Approaches in Africa}

While UNESCO Biosphere Reserves were established in Africa as early as the late 1970s ${ }^{2}$ [18], alternative approaches to natural resource management that integrate biodiversity conservation with the socio-economic development of local communities have gained prominence since the mid-1980s [4]. These approaches, which were first introduced by the World Wide Fund for Nature (WWF), can be summarized under the term Integrated Conservation and Development Projects (ICDPs) [32,33]. Biosphere reserve initiatives and ICDPs interacted or complemented each other, primarily where both approaches coincided on site, as described in Section 4.1 for Ghana [30,34].

\subsubsection{Development of Alternative Approaches over Time}

Until the 1970s, land management in many African countries was mostly conducted under sectoral approaches. While many traditional African societies used to apply holistic approaches to administer their natural resources, the socio-economic consequences of colonial and post-colonial governance systems led to landscapes that were widely characterized by single-purpose and exclusive-use approaches, with the management and distribution of land under the broad authority of central governments. Often the needs of local communities were not reflected in landscape planning, as shown in reports about the relocations of populations for different purposes of land use [29,35].

The conservation sector, until the 1970s, focused primarily on the preservation of natural landscapes inside protected areas. It widely ignored the situation outside conservation sites and the roles of humans in maintaining them. Beyond legally protected areas, natural resources on communal lands were-mainly as a result of population pressure-increasingly affected by the overutilization and

2 Today, 79 UNESCO Biosphere Reserves have been designated in 29 African countries [18]. 
degradation of natural resources and a loss of biodiversity [36]. Realizing these flaws and their consequences for general environmental protection at the end of the 1970s, conservation across Africa experienced a change in mindset [33]. It was acknowledged that previous conservation approaches, which focused primarily on the establishment of protected areas, had been ineffective in stopping general habitat losses and the poaching of protected species [37]. Moreover, conservationists realized that protected area development in the past often came with social injustices among local populations [33].

On these grounds, ICDPs promoted a shift from the "traditional fortress conservation model" [12] towards integrated approaches, which included the livelihood needs of local communities. While the literature assessed the implementation of this "first generation of ICDPs" [4] as predominantly oriented towards conservation with often only symbolic participation mechanisms for local communities, they were forerunners of a paradigm shift in addressing land management and conservation [4], specifically in Africa but also in other parts of the world [32,38]. This movement was fostered through the parallel emergence of the scientific discipline of "Landscape Ecology", which aims to better understand the relationship between spatial formations and ecological processes at different scales and levels of organization [12].

In the 1990s, change could also be observed in the field of development cooperation. Biodiversity was increasingly addressed as a socio-economic asset for economic development, which led to the growing integration of conservation perspectives into the conceptualization of rural development projects [12]. The development theory discourse in the 1980s changed and began to emphasize in particular the potential of decentralization and local empowerment approaches [12]. For these reasons, in the late 1980 and early 1990s, ICDPs became increasingly popular development instruments. Following the Rio Conference in 1992, a number of different integrated landscape approaches gained further popularity, e.g., under the names of integrated natural resource management, integrated rural development or community-based natural resource management (CBNRM) [12]. While these approaches have been differentiated in the literature, it is important to stress that, in practice, they often represent similar initiatives, albeit applied within different contexts and under different strategies [12].

\subsubsection{The Case of Community-Based Natural Resource Management}

The CBNRM approach gained high levels of attention in the conservation and development sectors, especially in southern Africa, and has been vital for the implementation of many ICDPs since the 1990s. While under colonial and post-colonial legislation, the utilization of wildlife through local communities was broadly prohibited; however, in the 1970s and 1980s perceptions towards wildlife use rights started to slowly change in some countries [34]. New laws would allow private landowners and communities to make use of local natural resources and directly benefit from wildlife on communal lands. The first large-scale CBNRM-project was CAMPFIRE (Communal Area Management Program for Indigenous People) in Zimbabwe. This project was launched in 1989 and implemented at the district level, promoting income generation for communities through the sustainable use of natural resources, mainly by licensing wildlife access to safari and tourism operators [36,39]. The implementation in Zimbabwe sparked the introduction of similar programs in other countries, such as in Botswana, Mozambique, and Namibia. During this time, CBNRM became part of the development strategies and conservation policies in a number of countries and was increasingly supported by international funding organizations, the African Union (AU), and multilateral organizations [34].

CBNRM-approaches can take many forms and emphasize different subjects according to their regional or national implementation contexts or corresponding bio-geographic landscapes. CBNRM can be implemented as communal conservancies, as in the case of Namibia; as Community Resource Management Areas (CREMAs), to regulate natural resources in the forests of Ghana; or as Wildlife Management Areas (WMAs), such as in Tanzania. In some countries, CBNRM is predominantly regarded as a rural development tool; in others, there is a clear emphasis on the conservation aspect of CBNRM and its potential to protect ecosystems [34,36]. While the scope and scale of CBNRM-approaches 
differ, they all share the general principle of advancing the sustainable management of wildlife and natural resources while fostering the empowerment and livelihood of local communities [40]. In all instances, CBNRM involves some degree of the co-management of resources between central authorities, the local government, and local communities, which share rights and responsibilities through diverse institutional arrangements [34]. The conservancy-approach, as implemented (e.g., in Namibia), is based in particular on relatively broad-based stakeholder participation and the devolution of management rights over local resources to local communities.

Despite mixed performance assessments [34], due to its potential for inter-sectoral sustainable development, CBNRM has been widely acknowledged by conservationists and development organizations as a useful tool to foster conservation and livelihoods and to implement international agreements, conservation strategies, and development agendas, such as the Convention on Biological Diversity (CBD). All over Africa, CBNRM-projects have become important partners for international organizations to test innovations related to linking environment and development, finance mechanisms (like Payments for Ecosystem Services), or innovative approaches associated with climate change adaptation $[4,34]$.

\section{Methodology}

\subsection{Analytical Framework}

This study follows the broad definition of Reed et al. [12], who understand a landscape approach "as a framework to integrate policy and practice for multiple competing land uses through the implementation of adaptive and integrated management systems". Based on a review of the literature on key aspects of the effective implementation of landscape approaches [12,41,42] and with special regard to the work of Sayer et al. [3], a set of four interlinked components for a successful landscape approach was synthesized ${ }^{3}$.

Governance systems lay the foundation for policy and project implementation in a landscape setting. They are highly context dependent, and their structures vary widely between landscapes. Every landscape approach should ideally be designed according to the specific stakeholder configurations and their goals and targets [12]. Therefore, already in the initiation process, implementing actors need to evaluate adequate institutional structures to address the multifunctionality of a landscape, its openness towards stakeholder participation, and guarantee transparency and compliance towards the existing rules of land use in the designated area [3]. Adaptive management is key to addressing the dynamic processes within landscapes and their stakeholder configurations and to mitigating the intersectoral consequences of unforeseen changes in individual parts of the landscape [12,44]. Adequate information and communication are preconditions for stakeholders to participate and engage effectively and fulfill their roles in a landscape arrangement. Transparent communication of the aims, targets, benefits, and potential trade-offs contributes to stakeholders' trust in the legitimacy of the implemented approach [3]. Strengthening the capacities among stakeholders can further contribute to reducing power inequalities among stakeholders and providing knowledge for further development of the landscape. Multi-stakeholder participation and engagement constitute a condition for the aforementioned three components to be realized along with a base for developing general consensus and entry points for all stakeholders [3,41,42].

3 This synthesis mainly draws on the work of [3,12,42] Sayer et al. [3], who developed a set of 10 principles to guide the process of decision-making and reconciling competing land uses in landscapes. Representing a consensus view of professional institutions, these principles were also discussed at the 15th meeting of the Subsidiary Body on Scientific, Technical, and Technological Advise of the Convention of Biological Diversity (CBD) and later accepted by the CBD [3,43]. Based on a comprehensive review of landscape literature, Reed et al. develop five key aspects of an effective landscape approach. Ros-Tonen et al. synthesized five preconditions and three enabling conditions for adaptive landscape approaches and applied them to analyze the landscape governance potential of co-management systems for reforestation in Ghana. 
In the following, these four components-governance; adaptive management; information, communication, and capacity building; and multi-stakeholder participation and engagement-will be used as analytical categories for the analysis of the potential of biosphere reserves for sustainable landscape governance and management. We thus assume that the components relate to each other as outlined in Figure 2.

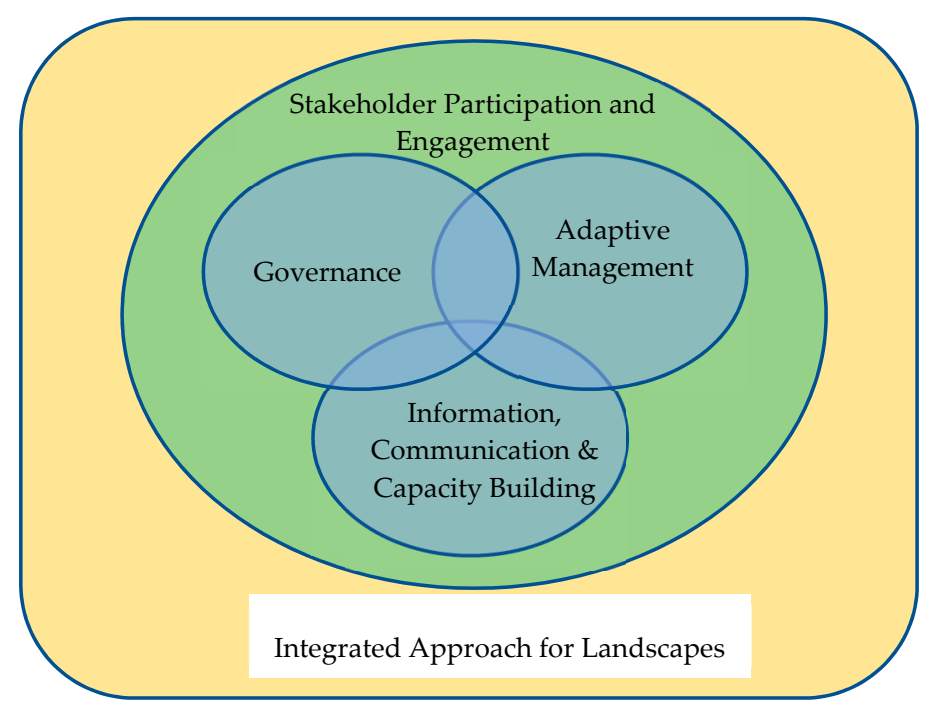

Figure 2. Analytical framework for a study on the potential of biosphere reserves for landscape governance and management.

\subsection{Data Collection and Methodological Approach}

Methodologically, this analysis is based on a review of scientific work on the implementation of the landscape approach in Africa in general and on biosphere reserves in particular. The results of the literature review are summarized in Sections 2 and 4. The databases of WorldCAT, Wiley Online Library, and JSTOR were used to capture the current state of peer-reviewed literature using the key terms of this study. Moreover, online searches were conducted via Microsoft Academic Search and Google Scholar to complement the database research and to include relevant grey literature, primary sources, and non-peer-reviewed articles and books.

To supplement the literature review with practical insights and evidence, four biosphere reserves located on the African continent were empirically investigated. To select the case studies, the following criteria were considered: year of designation, ecosystem type, size of area and population, and governance and management system (Table 1). With the aim of reaching heterogeneity in these criteria among the four cases and exploring a geographical spread of cases across Africa, this selection resulted in the following cases: Mount Mulanje (Malawi), Vhembe (South Africa), Lake Bosomtwe (Ghana), and Mono (Benin/Togo). In each biosphere reserve, a comprehensive semi-structured interview (SSIs) was conducted. Considering the context sensitivity of the implementation practice in biosphere reserves and the intent to add in-depth insights from biosphere reserve practitioners, qualitative enquiries were chosen. The SSI-framework was selected, as its design allows one to acquire comparable qualitative information on the topic, while the interviewer remains responsive to the interviewee [45].

Interviewees were senior managers of their respective biosphere reserves. Interviews were conducted personally or via telephone and web-based telecommunication services between January and March 2020. The interview guide (see Appendix A) was designed analogous to the analytical framework described above and encompasses five sections to capture the following aspects: (1) general aspects on the biosphere reserve's vision, mission, initiation, and design; (2) governance; (3) management; (4) multi-stakeholder engagement; and (5) information, communication, and capacity building. All respondents were assured of their anonymity. 
Table 1. Selected features of the investigated biosphere reserves. Source [46-51] and our own interviews $[30,31,52,53]$.

\begin{tabular}{|c|c|c|c|c|}
\hline & $\begin{array}{l}\text { Mount Mulanje, } \\
\text { Malawi }\end{array}$ & Vhembe, South Africa & $\begin{array}{c}\text { Lake Bosomtwe, } \\
\text { Ghana }\end{array}$ & Mono, Benin/Togo \\
\hline Year of designation & 2000 & 2009 & 2016 & 2017 \\
\hline Ecosystem/landscape & $\begin{array}{l}\text { Mountain forest } \\
\text { and surrounding } \\
\text { lowlands }\end{array}$ & $\begin{array}{l}\text { Savannah, } \\
\text { agro-cultural } \\
\text { landscape }\end{array}$ & Lake, forest, mountain & $\begin{array}{l}\text { Alluvial plain and river } \\
\text { delta and bank areas }\end{array}$ \\
\hline $\begin{array}{c}\text { Surface area, } \\
\text { terrestrial and marine } \\
\left(\mathrm{km}^{2}\right)\end{array}$ & 563 & 30,101 & 287 & 3463 \\
\hline $\begin{array}{l}\text { Population in the area } \\
\text { affected by biosphere } \\
\text { reserve activities }\end{array}$ & 350,000 & $1,500,000$ & 50,000 & $2,000,000$ \\
\hline $\begin{array}{c}\text { Main economic } \\
\text { activities of the local } \\
\text { population }\end{array}$ & $\begin{array}{c}\text { Small-scale } \\
\text { agriculture (crop } \\
\text { production, fruit } \\
\text { trees, tea, } \\
\text { beekeeping, } \\
\text { bamboo, } \\
\text { fish-farming) }\end{array}$ & $\begin{array}{c}\text { Small-scale and } \\
\text { large-scale agriculture } \\
\text { (fruit trees, vegetables), } \\
\text { trade }\end{array}$ & $\begin{array}{c}\text { Farming, fishing and } \\
\text { tourism }\end{array}$ & $\begin{array}{l}\text { Small-scale agriculture } \\
\text { (oil palm and coconut } \\
\text { palms), pasture, } \\
\text { forestry and fishing }\end{array}$ \\
\hline $\begin{array}{l}\text { Organization in } \\
\text { charge of } \\
\text { management }\end{array}$ & $\begin{array}{l}\text { Mount Mulanje } \\
\text { Conservation Trust }\end{array}$ & $\begin{array}{c}\text { Vhembe Biosphere } \\
\text { Reserve }\end{array}$ & $\begin{array}{l}\text { Lake Bosomtwe } \\
\text { Community Resource } \\
\text { Management Area }\end{array}$ & $\begin{array}{l}8 \text { associations (for core } \\
\text { and buffer zone); } \\
\text { community/territorial } \\
\text { authorities for } \\
\text { transition zone }\end{array}$ \\
\hline $\begin{array}{l}\text { Focus of biosphere } \\
\text { reserve activities }\end{array}$ & $\begin{array}{c}\text { Mountain } \\
\text { conservation, green } \\
\text { economy activities }\end{array}$ & $\begin{array}{c}\text { Community } \\
\text { sensitization for } \\
\text { conservation and } \\
\text { sustainable } \\
\text { development, } \\
\text { education (youth) }\end{array}$ & $\begin{array}{l}\text { Research, especially on } \\
\text { climate change, } \\
\text { environmental } \\
\text { education for schools } \\
\text { and universities }\end{array}$ & $\begin{array}{c}\text { Capacity development } \\
\text { on conservation, } \\
\text { small-scale agriculture, } \\
\text { agro-forestry, fishing, } \\
\text { trade }\end{array}$ \\
\hline $\begin{array}{l}\text { Linking conservation } \\
\text { and sustainable } \\
\text { development } \\
\text { (examples of } \\
\text { measures) }\end{array}$ & $\begin{array}{c}\text { Fostering } \\
\text { partnerships } \\
\text { among } \\
\text { conservation and } \\
\text { development } \\
\text { organizations and } \\
\text { with private sector; } \\
\text { promoting } \\
\text { sustainable supply } \\
\text { chains; } \\
\text { demonstration } \\
\text { projects }\end{array}$ & $\begin{array}{c}\text { Community } \\
\text { sensitization for } \\
\text { conservation and } \\
\text { development through } \\
\text { demonstration projects; } \\
\text { interlinking biosphere } \\
\text { reserve concept with } \\
\text { general livelihood } \\
\text { matters; } \\
\text { capacity-building } \\
\text { workshops for local } \\
\text { communities }\end{array}$ & $\begin{array}{l}\text { Community } \\
\text { sensitization for } \\
\text { conservation and } \\
\text { sustainable } \\
\text { development through } \\
\text { demonstration projects; } \\
\text { capacity-building } \\
\text { workshops for local } \\
\text { communities }\end{array}$ & $\begin{array}{l}\text { Stakeholder projects } \\
\text { with regard to } \\
\text { sustainable resource } \\
\text { use, community } \\
\text { sensitization }\end{array}$ \\
\hline $\begin{array}{l}\text { Link to other/superior } \\
\text { administrative or } \\
\text { political levels } \\
\text { (examples) }\end{array}$ & $\begin{array}{l}\text { Member in } 57 \text { local } \\
\text { to national } \\
\text { committees, } \\
\text { including } \\
\text { traditional and } \\
\text { local government } \\
\text { bodies }\end{array}$ & $\begin{array}{l}\text { Limpopo Province } \\
\text { Department of } \\
\text { Economic } \\
\text { Development, } \\
\text { Environment and } \\
\text { Tourism; District } \\
\text { authorities; National } \\
\text { MAB Committee; } \\
\text { National Department } \\
\text { of Environmental } \\
\text { Affairs }\end{array}$ & $\begin{array}{c}\text { District councils, Water } \\
\text { Resources } \\
\text { Commission, Lake } \\
\text { Bosomtwe Community } \\
\text { Resource Management } \\
\text { Area Committees, } \\
\text { Bosomtwe District } \\
\text { Assembly, Bosomtwe } \\
\text { Freho District } \\
\text { Assembly, } \\
\text { Environmental } \\
\text { Protection Agency }\end{array}$ & $\begin{array}{c}\text { Community } \\
\text { authorities in Benin } \\
\text { and territorial } \\
\text { authorities in Togo and } \\
\text { close links to the } \\
\text { responsible national } \\
\text { ministries }\end{array}$ \\
\hline
\end{tabular}

\section{Analysis and Findings}

\subsection{Governance}

\subsubsection{The Governance Framework of Biosphere Reserves}

UNESCO's MAB Program allows for a flexible biosphere reserve governance structure design. The Statutory Framework of the World Network of Biosphere Reserves explicitly emphasizes the 
importance of diversity and encourages the development of national implementation structures that consider specific national contexts [20]. This consideration is related to a recognition of the peculiarity of landscapes worldwide with regard to: their biophysical features and the differences in natural resource use, traditional and cultural values of landscapes, existing forms of stakeholder organization, and concerning institutional and political contexts. In practice, this flexibility has led to a broad variety of governance approaches among biosphere reserves. In some cases, biosphere reserve governance structures are part of national, provincial, or municipal administrative authorities and may be considered in legislation. In other cases, biosphere reserves are managed by, or function as, non-governmental organizations (NGOs) or are under some form of private management $[54,55]$.

While appreciating the diversity in national implementation contexts, governance structures should be in the position to promote the realization of a biosphere reserve's functions and to address the broad participation of stakeholders. Moreover, institutional structures should provide adequate mechanisms to foster sustainable resource use and human activities [20]. Due to the aforementioned diversity of governance models, it is difficult to describe how biosphere reserves generally implement these institutional expectations. However, two typical models (see Figure 3), categorized by their organizational forms as the "authority model" and "NGO model", are described in a management manual for African biosphere reserve managers, compiled in cooperation between the AfriMAB, the UNESCO MAB Secretariat, and the German Commission for UNESCO in 2015 [55]. Notably, these two models represent ideal types based on comprehensive experiences with biosphere reserves in Sub-Saharan-Africa. Most biosphere reserves may find themselves somewhere on the spectrum between these two model poles, but a basic understanding of the fundamentally different governance approaches is helpful for understanding the structure and functioning of a specific biosphere reserve.

Both models share a similar composition in their organizational bodies in the form of a "managing body" that executes the daily work of the biosphere reserve; an "executive body", responsible for decision-making; and an "advisory body" to ensure an informed decision-making process. In the authority model, the management body is in some way connected to a supreme governmental authority, such as a national or provincial ministry. Executive decision-making takes place within this authority, and the management body is legally authorized to implement its decisions. This structure equips the management body to have a strong administrative mandate in the designated area, which is usually bound to the mandate of the responsible governance authority, e.g., national parks and wildlife or forestry. As such, the executive or management body has only limited opportunities to engage in activities that fall under the mandate of other public authorities, such as agriculture, tourism, water, or education. Sometimes, the mandate of the management body is limited to the core zone only [55].

Among the four case studies, Lake Bosomtwe Biosphere Reserve (Ghana) provides an interesting example, with its governance structure integrated into an pre-existing administrative structure. The latter represents a several-tier system of traditional and political authorities that embodies the base of the local political system. To ensure adequate management of the biosphere reserve, the "Lake Bosomtwe Resource Management Area" (CREMA) was established to function as the main governance and management entity of the area [35]. CREMAs are a tool for communities in Ghana to manage their use of natural resources [34]. The establishment of the Lake Bosomtwe CREMA was conducted with special regard to existing traditional decision-making structures within the Ashanti region. The CREMA's constitution was legalized by a by-law of the two respective district assemblies, which have general oversight of the decisions of the CREMA board. The constitution foresees the inclusion of individual representatives of all engaged government agencies and the two district assemblies as ex-officio members into the board [37].

According to the NGO model (see Figure 3), a biosphere reserve is not directly connected to any public authority but functions as an independent organization. Its main decision-making body is composed of different relevant stakeholder groups, such as landowners, entrepreneurs, and researchers, as well as national or provincial public authorities. As this executive body has no supreme administrative mandate beyond the biosphere reserve, the management body has less or no formal 
authority to implement its decisions in the designated area [55]. Therefore, it functions instead as a coordinator for implementing different activities and projects towards the biosphere reserve's goals together with local and sometimes international partners. Without an "official" mandate for its management body, the relevance of the biosphere reserve highly depends on its acceptance by local communities and local political stakeholders [16]. However, functioning similar to an NGO can also provide the management body more leeway in implementing projects and, thereby, enhance its credibility as a politically independent organization [55].

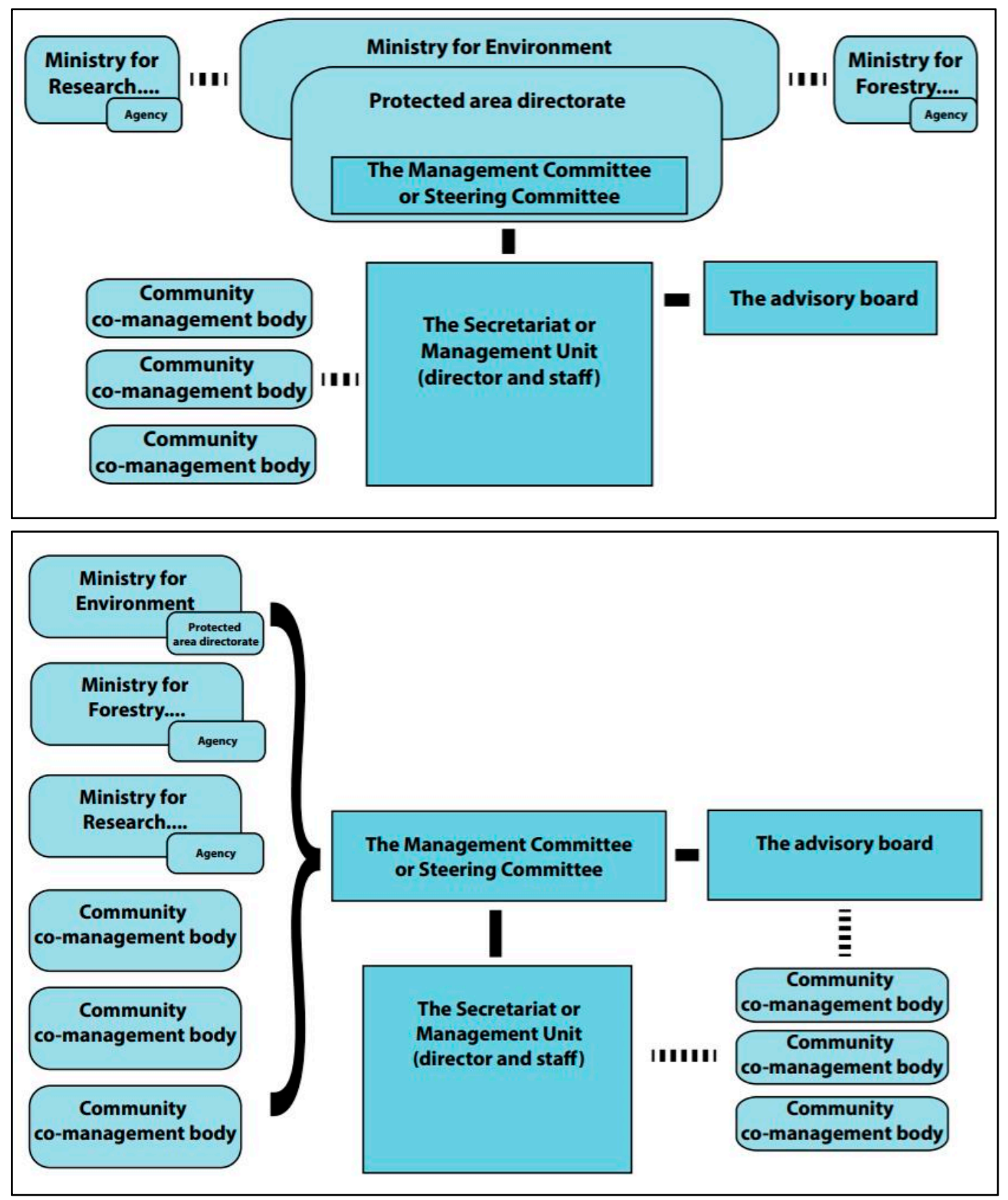

Figure 3. Two exemplary governance models for biosphere reserves: the authority model (above); NGO model (below). Source: [55].

To illustrate a biosphere reserve structured according to the NGO model, we consider the example of the Vhembe Biosphere Reserve (South Africa). The Vhembe Biosphere Reserve understands itself as a non-profit organization that aims to work towards the objectives of the MAB Program [31]. The main decision body is the board of directors of 8-10 honorary persons who are representatives of different local 
individual or institutional stakeholder groups. They are elected for a period of three years during the annual general meeting by the Vhembe Biosphere Reserve members. An additional board seat (without voting rights) exist for a representative of the Limpopo Province Department of Economic Development, Environment and Tourism, to represent the responsible governmental authority with the strongest executive mandate in the region. Additional board seats were established for the administrations of the four districts that form part of the biosphere reserve to link the biosphere reserve to local political and administrative structures. They advise the board from the perspective of the relevant public authorities. The board of directors holds five sub-committees tasked to elaborate information on conservation, development, research, education, communication, and finance. All management activities and projects are coordinated by a coordinator and his or her co-worker [31].

The NGO model is less common in African countries but is prevailing in South Africa [47]. In this category, the level of influence between public authorities and local stakeholders differs widely, sometimes leading to complex interconnections between different levels of local governance and stakeholders. This is especially true for biosphere reserves in countries where devolution processes towards land use and natural resource management have taken place in recent decades, and local institutions possess or share ownership of decision-making in the management of land use [55].

\subsubsection{The Biosphere Reserve Zonation as a Tool to Structure Governance}

Zonation is an important feature of a biosphere reserve but is also often highly contested. Hence, the involvement of stakeholders and their acceptance of zonation is crucial to adequately address and fulfil a biosphere reserve's functions [56,57]. In practice, zonation is the result of negotiation processes over different types of land uses and the needs to consider existing local development plans, such as plans for infrastructure or industrial development [10].

At Lake Bosomtwe Biosphere Reserve, the core of the lake along with several smaller areas next to the waterside have been designated as separate core zones surrounded by a buffer zone around the lake and a transition zone at its outer edges. What makes this zonation pattern of nested circles so special is that it is based on the preexisting cultural zonation of the local communities that inhabit the area. For centuries, fishermen have not fished at the center of the lake, which is regarded a sacred place.

This cultural taboo has, therefore, been transmitted into the so called "cultural core area" [55]. Agreeing on the concrete zonation for Lake Bosomtwe was a complex process, as three different government agencies (Forrest Services, Water Resource Commission, and "Spatial planning and Land use") were previously involved in managing the land use in the area and had divergent opinions on how to implement a zoning scheme within the areas under their specific mandates. However, through their integration and cooperation within the CREMA (see Section 4.4), they jointly reviewed their earlier proposals and came to an agreement for joint zonation of the area [30].

Once the zones are established, promoting compliance and implementing conflict resolution is an important task, which ideally should be embedded in governance structures. To resolve conflicts over natural resource use that contradicts the zonation, the Vhembe Biosphere Reserve constantly sensitizes local communities and takes a constructive approach to integrate the stakeholders concerned. In recent years, mining activities that affected the buffer zones developed and became an important economic sector in the region. The Vhembe Biosphere Reserve facilitates the exchange and agreements between mining companies, the provincial government, and local communities, who are engaged by enabling Environmental Impact Assessments. If necessary, governance structures are adapted to accommodate for emerging issues and new stakeholders [31].

\subsubsection{Initiating a Biosphere Reserve and Shaping its Governance}

The prevailing governance approach for biosphere reserves is also defined by the way that biosphere reserves are initiated. In some countries, a formal decision of the government is the first trigger to establish a biosphere reserve [10]. However, a successful UNESCO designation demands a broad consensus among local stakeholders [58]. The nomination dossier needs the approval of all 
relevant authorities and local mandate holders of the respective communities. Therefore, biosphere reserve initiators need to engage local stakeholders during the nomination process to jointly develop a common vision for the area and find consensus on the appropriate zonation. In some cases, this can lead to a lengthy process of several years, depending on the pre-existing experiences of the stakeholders with similar processes and potential conflicts that may emerge in the process [10,48].

In the case of South Africa, most biosphere reserves were established under the initiative of local stakeholder groups that decided to cooperate as non-profit organizations with provincial and national authorities towards developing a biosphere reserve designation [48]. For the Vhembe Biosphere Reserve, a group of local land and conservancy owners began the nomination process. With the support of the Limpopo Provincial Government, they reached out to local communities within the proposed area to inform them about the concept, to negotiate the proposed zonation approach, and to achieve the necessary acceptance from political and traditional leaders [31].

In Ghana, the process to establish the Lake Bosomtwe Biosphere Reserve was initiated by the government through the Environment Protection Agency (EPA), an agency subordinated to the Ministry of Environment, Science Technology, and Innovation. The EPA hosts the chair of the national MAB Committee and initiates MAB-related activities. Before the nomination project started, a cooperation project of the government of Ghana, UNESCO, and local community authorities was conducted to sensitize local communities to the biosphere reserve concept and to guarantee the local population's support for the implementation of a CREMA as the main governance and managing body of the biosphere reserve [30].

\subsection{Adaptive Management}

\subsubsection{Management Structures across Case Studies}

Biosphere reserve governance structures, as outlined above, strongly impact management procedures and performance. As we observed, the various institutional models (see Section 4.1), specific features of management related to human capacity (including: staff time, knowledge, and experience), relations to stakeholders, and access to finances and infrastructure differ substantially across biosphere reserves. The decision on which organization will assume management will strongly influence a biosphere reserve's orientation and ultimately its performance. Table 1 gives an overview of the management organizations responsible for implementation in the four biosphere reserves investigated in this study.

Mount Mulanje Biosphere Reserve is managed by the Mount Mulanje Conservation Trust (MMCT), an NGO established in Malawi in 2000, the same year the biosphere reserve was designated by UNESCO. In 2005, it became a conservation trust funded by the World Bank through the Global Environmental Facility. MMCT shares its goals with those of the biosphere reserve. These goals basically entail conservation of the mountain's natural resources, primarily focusing on water, soils, and biodiversity, and the promotion of people's livelihoods through sustainable resource use to help develop a Green Economy. Economic activities are related to the production and marketing of, for example, tea, fruit trees, fish, and timber [52].

The Vhembe Biosphere Reserve functions as an NGO and is coordinated through a non-profit organization of the same name. Decisions made by the board are primarily implemented by a financed coordinator and a number of supporting volunteers [31]. Quite differently, at the Lake Bosomtwe Biosphere Reserve, a CREMA and its local units, CSRMs, form the management unit of the biosphere reserve. The activities connected to the Biosphere Reserve are coordinated by two employees of the Water Resource Commission, the national agency responsible for water management in Ghana, which is also a CREMA stakeholder. At the transboundary Mono (River) Biosphere Reserve in Benin and Togo, eight local protected area associations, composed of land-owners and users, local NGOs, and other conservation initiatives, were established and officially given the mandate to manage the eight 
core and adjacent buffer zones. The transition zone is managed by community authorities in Benin and territorial authorities in Togo [46,53].

A characteristic of each investigated biosphere reserve is that the core management unit is very small. However, these units are supported by their respective executive boards and/or an advisory board. Moreover, management often cooperates with different governmental, non-governmental, and/or private sector supporting entities. This cooperation substantially increases management's capacity for implementation. For example, at the Mount Mulanje Biosphere Reserve, through close partnerships of MMCT with other organizations that operate in the area (who, contrary to MMCT, have a stronger focus on social matters like health and alphabetization), synergies evolve. This cooperation contributes to local sustainable development and serves as a mechanism to overcome the capacity limitations of MMCT. In practical terms, these partnerships involve the sharing of infrastructure or the mutual use of implementation tools. An example of shared tools are the so-called community profiles, which reflect communities' needs and priorities in the region and are developed by MMCT in cooperation with local communities [52].

In the Mono Biosphere Reserve protected area, associations have developed close links to official law enforcement agencies, especially the police, foresters, and courts. These links have significantly helped increase adherence to internally negotiated regulations and use restrictions for the core and buffer zones. In addition, links to private sector companies, as recommended by UNESCO [20] (e.g., to a nearby limestone mine), resulted in additional support for conservation activities in the biosphere reserve [53]. Positive experiences and intentions to further engage with the private sector were also mentioned by other biosphere reserve managers [30,31,52]. Experience from the WNBR showed that private sector engagement in conservation and development initiatives is often motivated by image gains and, in some instances, by economic factors [59].

\subsubsection{Specific Management Challenges and Tools}

In a multi-stakeholder landscape setting, conflicts inevitably emerge. This raises the question of how biosphere reserve managers can cope with such challenges. What mechanisms have worked to address and ultimately solve such conflicts, and what role does the zonation of a biosphere reserve play in this regard? In the Mono Biosphere Reserve, prior to its establishment, hardly any gazetted protected areas existed. Hence, the core and buffer zones were identified in an intensive stakeholder dialogue process that focused on communities' land use practices and future plans and included training on ecological interrelations. Zones were ultimately identified considering breeding grounds for fish, the reproduction of timber, or grassland restoration for communal grazing. Following the identification of the zones, associations were established and officially mandated to manage the core areas. Furthermore, rules and regulations were set and subsequently enforced with the support of the relevant authorities. The zonation requirements for the designation of the biosphere reserve stimulated a negotiation process that resulted in the protection of sites for communal rather than individual benefits. Today, the communally negotiated and clear zonation of the area has contributed to reducing conflicts rather than increasing them [53].

For the Vhembe Biosphere Reserve, as for numerous other protected areas, mining activities within or near the biosphere reserve are usually a matter of conflicting interests. The designated South African Energy and Metallurgical Special Economic Zone (established 2017) is mainly located in the Vhembe Biosphere Reserve [60]. While communities anticipate employment opportunities through the large investments (as planned for), conservationists and farmers fear negative impacts on the environment, specifically impacts related to the availability of already scarce water resources. The Vhembe Biosphere Reserve management understands itself as a broker in this conflicting situation and contributes by providing a negotiation platform and relevant information [31].

A major tool for biosphere reserve management—and a UNESCO requirement [20] — is a management plan. These plans differ substantially in terms of their implementation periods (from 2 to 5 years among the four case studies) and their details. The Mount Mulanje Biosphere Reserve 
operated in the past on the basis of a 5-year management plan that focused specifically on the forest sector. This emphasis was due to the fact that the biosphere reserve is located in a forest reserve and overseen by the Department of Forestry. Subsequent to its periodic review of 2014, UNESCO advised the biosphere reserve to consider expanding its boundaries beyond the forest reserve. This suggestion catalyzed management's thinking towards an integrated management plan that also reflects others sectors that form part of the management's activities in the region, including water, energy, agriculture, and tourism. As a result, a comprehensive, integrated plan is currently being elaborated (with external financial support) [52].

Funding is a major requirement for the provision of management services in a biosphere reserve. Financial resources are needed for the remuneration of staff (if employed directly by the biosphere reserve), any management activities and operations (including meetings, transport, etc.), as well as conservation and development projects implemented with local stakeholders. Funds derive from various sources: the government (primarily national or provincial governments), NGOs (local, national, or international NGOs), and private sector companies within or beyond the biosphere reserve. Their availability and continuity largely impact a biosphere reserve's potential to advance its goals. Hence, expanding a reserve's funding portfolio and applying for funding is a central task of biosphere reserve management. For example, the MMCT in charge of the Mount Mulanje Biosphere Reserve's management developed an endowment fund that is currently around 6 million US\$. This fund generates annual revenue; it is supplemented with funding from other sources (including international donor contributions and returns form MMCT's own electricity company) to implement community projects [52].

More generally, with respect to a biosphere reserve's dual goal of conservation and sustainable development, the question arises how management can successfully link these goals—specifically in a landscape categorized by zonation. A strategy followed by the Mono Biosphere Reserve is to demonstrate the economic value of conservation measures to stakeholders. Ecotourism activities in the buffer zone generate employment and income. For example, conserving breeding grounds for fish improves returns from a fishery over the long term, and simple methods to produce compost increase crop yields [53]. Activities that connect stakeholders' needs to the vision of the biosphere reserve enhance understanding and trust in the biosphere reserve.

\subsection{Information, Communication, and Capacity Building}

Logistical support, which (according to the MAB Program) includes research and monitoring, as well as education, training, and demonstration projects in relation to conservation and sustainable development, is one of the three basic functions of a UNESCO Biosphere Reserve $[10,20]$ (see also Section 2.1). Logistical support is of specific relevance for socio-ecological systems, where strong interconnections and correlations between biophysical and social factors exist. Moreover, the changing conditions in landscapes—such as those induced by climate change-necessitate further investigations, testing, and constant adaptation [9]. The insights obtained from the four case studies show that by connecting different components of logistical support, effective sustainability outcomes can be achieved.

The academic staff of the University of Venda, located in the Vhembe Biosphere Reserve, played a central role in establishing the biosphere reserve, and scientists are still part of the board. This circumstance has shaped and influenced the activities of the biosphere reserve. Scientific input from affiliated researchers contributed to the provincial government's Bioregional Plan for the Vhembe District, and the biosphere reserve remains a competent scientific partner of the government [31]. Furthermore, through communication and close links between researchers and biosphere reserve management, emerging issues and questions with research relevance can be directly taken up and investigated within the area. This process strengthens the relevance and application of the applied research results. For example, the research conducted by the University of Venda on crop pest predation by bats and birds in macadamia orchards provided significant results for the local fruit and nut tree industry [61]. 
In general, the links and relationships to other national and international universities that may develop through the WNBR can result in valuable scientific exchange. This may lead to the testing and application of new research approaches or methodologies on landscapes, mutual projects, additional external research funding, and a broader recognition of the results. Current literature on the role of protected area networks and international research collaboration highlights this potential $[62,63]$. Biosphere reserves, specifically, are well suited for transdisciplinary research approaches, once stakeholders appreciate and value the concept [64]. Moreover, the involvement of students in research projects connected to the biosphere reserve can help broaden students' understanding of landscape approaches and system analysis.

In the Mount Mulanje Biosphere Reserve, an evaluation of the mountain's resources and related livelihood activities—carried out with support of the Massachusetts Institute of Technology—provided central information for a new management plan that is currently under preparation. Following appropriate educational measures for community members, today, people better realize the interconnections between natural resources and act accordingly. In addition, the biosphere reserve framework itself has proven to be a useful tool for managing its communication with governmental authorities and international organizations [52].

Besides university students, young people are, in general, an important target group for the Vhembe Biosphere Reserve, partly because of their function as multipliers for aged family members and partly due to their role as future decision makers. In addition, young people are usually easy to reach and communicate with via social media. At the Vhembe Biosphere Reserve, the focus on youth is reflected in a number of activities that include hosting of the first African Youth Biodiversity Forum in early 2020, regular football camps for students linked to raising awareness for conservation (and plans for a conservation school contest), an award for young recycling champions, and an app to exchange information on topics that are of specific relevance to biosphere reserve residents (e.g., information on water shortage) [31].

Across the investigated biosphere reserves, demonstration projects proved to be effective tools to build capacity and communicate the practices of sustainable production and processing. At the Mono Biosphere Reserve, a large demand for capacity-building activities exists that links conservation with the sustainable use of natural resources. Demonstration projects that, for example, showcased activities related to vegetable gardening, tree nurseries, the production of compost or biochar to improve soil properties, or sustainable fishery practices were most successful when carried out on the properties of the target group and through personnel not only knowledgeable in the subject matter but also very familiar with the circumstances, values, and culture of the target group. The immediate benefits derived from the implementation of new technologies for stakeholders are crucial, but medium and long-term benefits are also recognized and valued by communities [53].

A frequent challenge for biosphere reserve managers is to direct stakeholders' expectations towards a realistic perception of future benefits of the biosphere reserve and the necessary contributions as stakeholders to achieve these benefits. To avoid a cycle of "optimism and disenchantment" [16], which might have serious consequences for stakeholders' acceptance of the biosphere reserves, clear communication of the potential benefits, trade-offs, and prospective timeframes is crucial. In this context, the Lake Bosomtwe Biosphere Reserve is conducting consultations and capacity-building activities with local communities to provide knowledge about the necessary preconditions for scaling up the tourism industry around the lake [30].

\subsection{Multi-Stakeholder Participation}

Regardless of the specific governance approach, stakeholder participation is one of the core conditions for a successful implementation of the biosphere reserve concept. The Statutory Framework of the WNBR lists the provision of participation opportunities for stakeholders as one of its central criteria for designating a biosphere reserve [20]. Research results shows that biosphere reserves that fail to effectively engage their relevant stakeholders endanger their sustainability in the long-run $[10,16]$. 
As a biosphere reserve combines different sectors within a given area and aims to cooperate with different networks of local stakeholders, coordinating between stakeholders, enabling engagement with the biosphere reserve structures, and moderating conflicts among stakeholders are key tasks of biosphere reserve managers and other affiliated actors (see Section 4.2). The biosphere reserve concept thereby allows for comprehensive approaches to achieve effective stakeholder participation with diverse entry points in the process for initiating, planning, implementing, and monitoring a biosphere reserve [56].

Participation should ideally begin in the initiation phase of a biosphere reserve, before any binding decisions are made regarding its establishment or specific zonation. This is necessary to create a shared vision between all potentially affected stakeholders that can legitimate the biosphere reserve among the local population [56]. Moreover, the early participation and integration of local stakeholders' knowledge into the development process of a biosphere reserve allows the construction of adapted structures, the identification of functional zones, and the development of early partnerships between the management and population of the biosphere reserve [16,56].

Usually, the first step of the participatory process begins with the identification of the stakeholder groups relevant for the biosphere reserve. Although, according to the biosphere reserve concept, all stakeholders within the area will ideally be involved, in practice, this is hardly feasible [56]. However, through traditional or local governance bodies, the indirect involvement of community members in decision-making processes may take place. Nevertheless, especially during the initiation phase, large parts of the population may not even consider themselves as stakeholders. Furthermore, as one of the interview partners of this study estimated, even after several years of existence, only about $10 \%$ of the local population might know of the existence and the functions of the biosphere reserve. Similar figures have been given by other biosphere reserves globally [65].

Due to their limited capacities, biosphere reserve managers usually work with specific stakeholder groups and their local representatives [55]. In practice, the choice of individual stakeholders for involvement in certain decision-making processes and their opportunities for participation are questions related to the biosphere reserve's governance and management structures and capacities (see Section 4.2) and the identification of relevant stakeholder groups in the area.

The Vhembe Biosphere Reserve in South Africa has made it a priority to involve as many individuals, communities, and organizations from the area as possible into its biosphere reserve structure. Each individual or institution situated in the area, e.g., smallholders, land-owners, village residents, business people, or NGOs, is entitled to become a member of the biosphere reserve by submitting a membership application and a formal declaration of support for the biosphere reserve's aims and objectives. Every member is consequently considered to be a stakeholder and categorized under a certain stakeholder group (e.g., farmers, landowners, or business owners) and has voting rights in the election of the board. Moreover, membership guarantees voting rights at the annual membership meetings and opportunities to become involved through contributions to the work of the advisory sub-committees $[31,50]$.

From a community perspective, the main function of the CREMA system in Ghana is to allow participatory decision making at the local level for commonly shared resources [51]. At the Lake Bosomtwe Biosphere Reserve, local stakeholders participate in decision making and implementing CREMA policies through their membership in the Community Resource Management Committees (CRMCs). The CRMCs are formed by the village units within the Lake Bosmotwe CREMA and include all residents and propriety owners within the catchment of the lake. The CRMCs thereby locally execute the CREMA's decisions while simultaneously holding the CREMA accountable through their representatives on the CREMA executive board [30].

The ability for biosphere reserve managers to convince potential stakeholders to engage in the biosphere reserve lies in the demonstration of potential "win-win" situations for conservation and local development and the collective sharing of potential benefits. Such benefits can come in a direct form, e.g., through income from tourism [25], or in an indirect form, e.g., through the improvement of natural 
resources as a result of conservation measures [55,56]. The concrete mechanisms used to sensitize local populations to the potential benefits of biosphere reserves and engaging stakeholders in such activities may, however, differ for specific stakeholder constellations on site. In all case studies, biosphere reserve managers predominantly approach and involve local communities directly through sensitization workshops, meetings, and demonstration projects. For conservation measures, it is important to attract community interest by demonstrating the economic benefits of such measures to stakeholders. As such, the Vhembe Biosphere Reserve aims to link its conservation work to current discussions on livelihood improvements in the area [31]. The Lake Bosomtwe Biosphere Reserve follows a similar path and sensitizes communities through specific projects, which are implemented through local CRSMs. These projects include a sustainable agroforestry initiative, as well as an education project in local schools to raise awareness of the benefits of proper sanitation and waste management [30]. To highlight the economic potential of the biosphere reserve, the Mount Mulanje Biosphere Reserve promotes the establishment of sustainable supply chains of agricultural products within the biosphere reserve. One of the successful initiatives of the biosphere reserve is the development of a smallholder tea production association, which includes more than 20,000 smallholders. The establishment of this association is an example of linking different stakeholder groups—in this case, smallholders and the tea industry—for mutual benefit.

\section{Discussion}

As interconnections in the landscape increasingly become a matter of research [2], as well as an appropriate spatial unit for the implementation of socio-ecological-systems [8,9] and sustainable development goals [66], this study aims to answer the question "what can we learn from the concept of UNESCO Biosphere Reserves and their implementation in landscape governance and management?" The analytical framework applied in this study defines stakeholder participation and cooperation as a "parenthesis" or necessary mechanism to advance conservation and sustainable development in a landscape. We also understand stakeholder cooperation as the basis for the planning and implementation of any conservation and development activity, especially at the interfaces of such activities. Moreover, as synthesized from the literature [3,12,42], governance, adaptive management, as well as information, communication, and capacity building are key analytical categories for sustainable landscape development. This study reveals the biosphere reserve practices and mechanisms that are useful for landscape governance and management. However, it also highlights the practical limitations of implementing the biosphere reserve concept. Below, we discuss the lessons learned with regard to the specific characteristics inherent to the concept of biosphere reserves.

\subsection{Identifying and Engaging Relevant Stakeholders as a Condition for Social Acceptance and Sustainability}

To gain the acceptance and support of local communities within a designated area, our findings show the importance of including relevant stakeholders in the processes for initiating, establishing, and managing a biosphere reserve. Clear participation opportunities and transparent governance structures are important to create trust between a biosphere reserve and its constituency. While this practice gives biosphere reserve management greater legitimacy among local communities, it can also lead to better informed, and thus more effective, decisions for interlinking conservation and development in a given area. Thus, stakeholder engagement is regarded as one of the main priorities by the four biosphere reserves investigated. The literature on landscape governance confirms that the participation of multiple stakeholders in decision making is key for successful cooperation across all sectors of a landscape [12,41]. In this context, the identification and mobilization of relevant stakeholder groups is considered a key factor for successful stakeholder involvement to achieve an "optimal, not maximal" [55] level of participation. This connects to Sayer et al.'s [3] findings on the importance of recognizing that all stakeholders are impacted by landscape processes, although the "efficient pursuit of negotiated solutions may involve only a subset of stakeholders". 


\subsection{Effective Communication of Potential Benefits and Trade-Offs}

Without being sufficiently informed and convinced of the potential benefits that may arise from a landscape approach, local stakeholders might continue to proceed with sectoral and unsustainable practices of natural resource use $[12,16]$. To inform local stakeholders of the potential benefits and inevitable trade-offs concerning land-use practices, all biosphere reserve managers interviewed for this article highlighted the importance of continuously sensitizing local communities through, for example, direct consultations, capacity-building workshops, or demonstration projects. The latter have proven to be especially effective tools for convincing local communities to possibly change their land-use practices to gain long-term oriented and sustainable benefits (e.g., in the field of ecological agriculture or tourism).

However, the analysis shows that it is important for stakeholders to obtain a true assessment of the outcomes of a suggested landscape approach and develop realistic perceptions of the necessary trade-offs and contributions. A landscape designation of an area, especially when it comes with an internationally recognized label, might easily lead to overly high aspirations for local income generation through conservation projects, such as in the form of (eco-)tourism growth or international funding. If these aspirations are not met, disenchantment amongst stakeholders could result in non-compliance with landscape-based conservation activities [16]. Therefore, management needs to clearly outline the necessary behavioral changes that a landscape approach demands and promote realistic expectations towards development outlooks and livelihood improvements.

\subsection{Flexibility of Governance Structures}

Another key lesson that can be drawn from this analysis is that the governance provisions of a landscape approach need to be flexible enough to adapt to specific regional, national, and local factors. Other authors confirm this observation and highlight the need for the contextualization of any landscape governance system $[3,12,41]$. As shown by the findings in Section 4 , the flexible biosphere reserve concept agrees with the notion of a "multi-level and cross-sectoral [governance] structure that benefits from the integration of internal traditional knowledge and external institutional and financial support" [12].

The four investigated biosphere reserves are organized and managed under different governance approaches: as an NGO (Vhembe Biosphere Reserve), as public associations (Mono Biosphere Reserve), through a conservation trust fund (Mount Mulanje Biosphere Reserve), or through a local collective form of community resource management (Lake Bosomtwe Biosphere Reserve). These, at least to some extent, fundamentally different institutional management structures emerge from the specific political contexts in their respective countries and local administrative hierarchies.

However, these approaches, except for the Lake Bosomtwe CREMA, share the characteristic that their executive body alone has no administrative sanctioning power to enforce its decisions. On the one hand, their authority relies on their credibility among local communities and their traditional leaders. This credibility can, among other solutions, be strengthened through co-management agreements, benefit-sharing models [25], and intensive consultation processes. On the other hand, as they are inherent to the biosphere reserve concept, biosphere reserve authorities rely on their relationship and adequate inclusion in regional or national administrative authorities (e.g., the provincial government or national ministry). Based on our findings described in Section 4, while formal independence from administrative authorities can weaken the executive power of a landscape approach and restrict its access to public funding, this independence can also strengthen the credibility of such authorities as politically independent institutions vis-à-vis their local constituencies and might ease access to external funding, such as through cooperation with international donors. 


\subsection{Effective Management Needs Coherent Concepts}

The management body of a biosphere reserve is the executive arm of the decision-making board and responsible for implementing its decisions, monitoring its compliance with zonation principles, and engaging with stakeholders. All investigated biosphere reserves highlight the role of short-term external shocks (e.g., floods, droughts) and changing socio-economic and ecological environments in shaping their management practices. Different forms of "adaptive collaborative management" [3] are, therefore, applied in the investigated biosphere reserves, although financial and staff capacities may limit the opportunities for adjustments in their management and continual learning practices. The results demonstrate that to enhance management capacities, applications for funding are a central task of biosphere reserve management to develop a diverse funding portfolio. The adoption, implementation, and constant adaptation of a comprehensive management plan and a corresponding business plan were identified as a prerequisite for a more coherent funding approach. Moreover, coordination and partnerships with local organizations that pursue similar goals in the landscape are proven to generate synergy and indirectly increase capacity.

\subsection{Zonation as a Tool for Managing the 'Multifunctionality' of a Landscape}

The zonation concept is the central tool of a biosphere reserve to balance economic development and conservation within a designated area. Simultaneously, zonation can also be one of the area's most contested features, as it spatially restricts land use for certain purposes. The application of the zonation approach in the investigated biosphere reserves, however, shows that it can be an effective tool to manage the "multifunctionality" [3] of a landscape and to address the associated trade-offs "in a spatially explicit and ecosystem-driven manner that reconciles stakeholders' multiple needs, preferences and aspirations" [3]. However, to achieve positive outcomes, the zonation approach has to be the result of an intensive negotiation process with affected stakeholders; it needs to reconcile the targets of a biosphere reserve with pre-existing development plans and land-use practices and to address the dynamics of land use practices in a landscape over time.

The integration into pre-existing land-management schemes and traditional approaches among the investigated biosphere reserves shows that the zonation concept does not have to be in conflict with pre-existing spatial practices. Rather, designation as a UNESCO Biosphere Reserve can up-scale previously integrated management efforts and achieve higher visibility for the designated area. Simultaneously, a biosphere reserve can also be integrated into existing local forms of resource management, like with Lake Bosomtwe Biosphere Reserve. Conversely, alternative natural resource management approaches (e.g., CBNRM) or schemes can form a part of, and help upgrade management efforts in, a larger landscape.

However, the case studies also showed that conflicting land-use aspirations of different stakeholders inevitably exist throughout a landscape. To identify and reconcile these conflicts may become a central task of landscape management $[3,6,10]$. Involving relevant stakeholders early in the zonation process was shown to be a viable approach to reach a common understanding for the zonation scheme. The case study findings demonstrate that stakeholder involvement should be context sensitive to convincingly affirm the value of a landscape concept. For example, the landscape concept could be explained with a model or (existing) demonstration projects. In this way, stakeholders could better understand the interrelated impacts (e.g., conservation and wildlife recovery in a certain area may foster economic benefits in another area through (eco-)tourism).

Lastly, analysis of the four cases revealed that the temporal dynamics of land use demands are as important as the different spatial land-use practices in a landscape at a given time. Changing economic and ecological demands can, however, necessitate the reconsideration of a zonation scheme. In this case, in the context of biosphere reserves, UNESCO's periodic review process can help support the participative re-zoning of the relevant landscape. 


\subsection{Strengthening Stakeholder Capacities and the Role of Partnerships, Research Collaboration, and International Networks}

To participate in landscape-oriented activities and accept diverse restrictions and aspirations within the same area, stakeholders need to be provided with the necessary knowledge and gain certain skills to engage in sustainable livelihood and conservation activities. As described above, biosphere reserve management addresses these issues, such as by offering sensitization workshops and implementing demonstration projects. However, although the need to strengthen stakeholders' capacities is consistently recognized [55], a lack of financial and human resources places severe limitations on capacity building. In this regard, incorporating local educational institutions as major stakeholders in landscape management to accommodate both training and research needs was shown to generate positive outcomes. Applied research results can further inform precise landscape planning or catalyze suitable innovations that may be integrated into educational material and thus again contribute to capacity building [67].

Funding from various sources is an important prerequisite to facilitate landscape management. As discussed, partnerships with organizations or companies operating within the area or the country may provide access to financial resources [55]. The biosphere reserve designation itself is no guarantee for funding, as no direct financial support is associated with the designation. However, as a member of the WNBR and its associated international recognition, the opportunities increase to participate in internationally funded programs or projects. Partnerships among biosphere reserves in the network worldwide may provide additional opportunities for contacts to fund their organizations. Hence, for any given landscape, partnerships or memberships with related or affiliated entities can lead to material and immaterial gains. In practical terms, these can include thematic exchanges for mutual challenges, staff visits, or joint projects, which might contribute to facilitating both the management and stakeholder communities within a landscape. Moreover, such networking can offer access to further partners and support, such as through private sector companies or donor agencies. The same holds true for establishing (international) research cooperation, which, as shown by the investigations, can provide external funding, expertise, and international prestige to a designated area as a "model region for sustainable development".

\section{Concluding Remarks}

The results of this study suggest that the governance and management features and tools of the UNESCO Biosphere Reserves that developed over the last 40+ years are of significant relevance for existing and emerging landscape approaches in Africa. In particular, this study shows that the following characteristics of biosphere reserves provide useful elements for landscape governance and management: (1) a flexible, content-specific governance approach; (2) efforts to connect the environmental and developmental sectors across a landscape; (3) the biosphere reserves' structural frameworks for management and planning; (4) a focus on capacity development and mutual learning among stakeholders; (5) landscape zonation as a tool to manage the multifunctionality of a landscape; and (6) stakeholder engagement as an overarching condition. This study also indicates that experiences with other natural resource management schemes, which have integrated conservation and sustainable development in Africa since the 1990s, offer valuable insight into further developing the landscape approach.

In this context, given the relative novelty of analyzing biosphere reserves under the analytical lens of the landscape approach, and due to the limited scope of this study, further research on this topic will be necessary. Moreover, additional analyses and discussions on different landscape governance and management approaches and practices in Africa would generally contribute to better understanding the factors and conditions for best practices and drawing more wide-ranging conclusions on the successful implementation of the landscape approach. 
Author Contributions: Work on the article's conceptualization, methodology, investigation, analysis, drafting, reviewing, and editing were equally shared among the two authors. All authors have read and agreed to the published version of the manuscript

Funding: This research received no external funding.

Acknowledgments: This article builds upon the authors' collaboration in research and development projects to support the advancement of UNESCO's MAB program and the development of biosphere reserves in Africa. These projects were carried out by the German Federal Agency for Nature Conservation with different African and international partner organizations between 2006 and 2019 and were funded by the German Ministry for the Environment, Nature Conservation, and Nuclear Safety. We sincerely thank the four anonymous interview partners from Mount Mulanje Biosphere Reserve in Malawi, Vhembe Biosphere Reserve in South Africa, Lake Bosomtwe Biosphere Reserve in Ghana, and Mono Biosphere Reserve in Benin and Togo for frankly sharing their knowledge, expertise, and experiences on biosphere reserves. We are also grateful to the four anonymous reviewers who, through their very valuable comments, encouraged us to significantly improve the manuscript.

Conflicts of Interest: The authors declare no conflict of interest.

\section{Appendix A}

Exploring the Potential and Contributions of UNESCO Biosphere Reserves for Landscape Governance and Management in Africa, with a Focus Stakeholder Engagement. Semi-Structured Questionnaire for Expert Interviews

Biosphere Reserve (BR):

Interview partner:

Date of (telephone) interview:

The questionnaire is divided into 5 Sections, aiming to capture indications on the following aspects:

(1) general aspects on the BR's vision, mission, initiation, and design of the BR

(2) governance

(3) management

(4) stakeholder engagement

(5) Information, communication, and capacity building

\section{BR vision, mission, initiation, and design (integrated approach and flexibility)}

1.1 What is the BR's vision (the desire for the future)? What is the BR's mission (objectives, approach-how will you achieve this vision)?

1.2 Who initiated the BR? Who (stakeholders/sectors) was engaged in the initiation process? What has been the decisive factor for the success of the nomination process? Which factors were stimulating/hampering?

1.3 Did national legislation have an impact on the nomination of the BR?

1.4 Which economic or social sectors (e.g., agriculture, education, etc.) play a role in the BR? What activities/measures does the BR support in its different sectors?

1.5 In how far does the BR contribute to the sustainable development (e.g., income generation and conservation) of the area?

1.6 What are the drivers for processes of change within the Biosphere Reserve?

1.7 Linking conservation and sustainable development (a major component of the BR concept) is not an easy task. How do you address this issue?

1.8 Is the UNESCO BR framework flexible enough to implement your concrete mission? (i.e., how much does the BR framework sufficiently respect the local context?)

\section{Governance}

2.1 What are the key structural elements, such as the board, assembly, committees, and working groups of the BR's governance system? Who are the members? What are their mandates? How do they operate (meetings, etc.)? 
2.2 Does your BR governance system function with regard to decision-making, planning, and implementation of activities in the BR (how)? What are the obstacles/success factors? Is transparency an issue?

2.3 Is the BR level linked to superior administrative or political levels (and if so, how?). Is this link supportive or hampering for achieving the objectives of the BR?

2.4 Is progress towards the vision/mission of the BR monitored? Is this useful, and are the results taken up?

\section{Adaptive Management}

3.1 Who is responsible for managing the activities of the Biosphere Reserve (staff, working groups, stakeholders, etc.)?

3.2 What are the mandates of the "managers", and who defines the mandate?

3.3 Does management work on the basis of a management plan? (Please explain.)

3.4 How flexible is the management in adapting to changing conditions?

3.5 What obstacles does management face, and what works well (examples)?

3.6 Are the financial resources of the BR a major issue for management (please explain)?

3.7 How does the BR management link conservation with sustainable development?

3.8 If you think about a landscape (approach), would you consider BRs suitable instruments for landscape governance and management? Why or why not?

4. Multi-stakeholder participation

4.1 Who is considered to be a stakeholder in the BR? (The all stakeholders versus selected stakeholders approach)

4.2 How important is stakeholder engagement in reaching the BR's objectives?

4.3 How (approaches, tools) do you engage with different stakeholders for the activities of the BR (entry points)? Do you address marginalized groups (youth, women) in a different manner?

4.4 How are benefits/costs shared among stakeholders; is the sharing of benefits/costs an issue or a source of conflict?

4.5 How does the BR ensure ongoing cooperation between stakeholders with different interests?

4.6 Are there (protracted) conflicts of interests between stakeholders in the BR (e.g., water access and land tenure)? Is the zonation a matter of conflict?

4.7 Does the BR take part in negotiating/moderating/reaching consensus between the different interests of different stakeholders? How do you do this?

4.8 What other mechanisms and institutions (e.g., justice system) for conflict resolutions within the landscape exist (beyond the BR)?

4.9 What recommendations could you give others working in landscapes with regard to factors for the success/failure of stakeholder cooperation?

5. Information, communication, acceptance, and Capacity Building

5.1 What information is needed to encourage that stakeholders accept and support the BR?

5.2 How are the BR communities sensitized towards the BR and its functions (which communication tools are used)?

5.3 What type of capacity building (and capacity building for whom) is important to achieve the goals of the BR (sustainable development)?

5.4 What are the obstacles and success factors concerning capacity building? 
5.5 To what extent does the BR contribute to providing information and capacity building? Apart from what you can do, what else would be important to best provide the necessary information to stakeholders?

5.6 Landscapes are constantly exposed to transformative change (due to population dynamics, climate change, etc.). What does this mean for the BR in terms of information and capacity building?

Are there any other issues you would like to raise or mention, or do you have a question yourself?

\section{References}

1. Förster, F.; Grossmann, R.; Iwe, K.; Kinkel, H.; Larsen, A.; Lungershausen, U.; Matarese, C.; Meurer, P.; Nelle, O.; Robin, V.; et al. What is Landscape? Towards a Common Concept within an Interdisciplinary Research Environment. eTOPOI 2012, 3, 169-179.

2. Freeman, O.E.; Duguma, L.A.; Minang, P.A. Operationalizing the integrated landscape approach in practice. Ecol. Soc. 2015, 20. [CrossRef]

3. Sayer, J.; Sunderland, T.; Ghazoul, J.; Pfund, J.-L.; Sheil, D.; Meijaard, E.; Venter, M.; Boedhihartono, A.K.; Day, M.; Garcia, C.; et al. Ten principles for a landscape approach to reconciling agriculture, conservation, and other competing land uses. Proc. Natl. Acad. Sci. USA 2013, 110, 8349-8356. [CrossRef]

4. Milder, J.C.; Hart, A.K.; Dobie, P.; Minai, J.; Zaleski, C. Integrated Landscape Initiatives for African Agriculture, Development, and Conservation: A Region-Wide Assessment. World Dev. 2014, 54, 68-80. [CrossRef]

5. Maitima, J.M.; Mugatha, S.M.; Reid, R.S.; Gachimbi, L.N.; Majule, A.; Lyaruu, H.; Pomery, D.; Mathai, S.; Mugisha, $\mathrm{S}$. The linkages between land use change, land degradation and biodiversity across East Africa. Afr. J. Environ. Sci. Technol. 2009, 310-311, 315-321.

6. Bavinck, M.; Pellegrini, L.; Mostert, E. Conflicts over Natural Resources in the Global South. Conceptual Approaches; Taylor and Francis: Hoboken, NJ, USA, 2014.

7. Walker, B.H.; Anderies, J.M.; Kinzig, A.P.; Ryan, P. Exploring Resilience in Social-Ecological Systems Through Comparative Studies and Theory Development: Introduction to the Special Issue. Ecol. Soc. 2006, 11. [CrossRef]

8. Folke, C. Resilience: The emergence of a perspective for social-ecological systems analyses. Glob. Environ. Chang. 2006, 16, 253-267. [CrossRef]

9. Bouamrane, M.; Spierenburg, M.; Agrawal, A.; Boureima, A.; Cormier-Salem, M.C.; Etienne, M.; Le Page, C.; Levrel, H.; Mathevet, R. Stakeholder engagement and biodiversity conservation challenges in social-ecological systems: Some insights from biosphere reserves in western Africa and France. Ecol. Soc. 2016, 21. [CrossRef]

10. Stoll-Kleemann, S.; Welp, M. Participatory and Integrated Management of Biosphere Reserves: Lessons from Case Studies and a Global Survey. GAIA 2008, 17, 161-168. [CrossRef]

11. Schultz, L.; Duit, A.; Folke, C. Participation, Adaptive Co-management, and Management Performance in the World Network of Biosphere Reserves. World Dev. 2011, 39, 662-671. [CrossRef]

12. Reed, J.; van Vianen, J.; Deakin, E.L.; Barlow, J.; Sunderland, T.C.H. Integrated landscape approaches to managing social and environmental issues in the tropics: Learning from the past to guide the future. Glob. Chang. Biol. 2016, 22, 2540-2554. [CrossRef] [PubMed]

13. Ishwaran, N.; Persic, A. Concept and practice: The case of UNESCO biosphere reserves. Int. J. Environ. Sustain. Dev. 2008, 7, 118-131. [CrossRef]

14. UNESCO. Biosphere Reserves: World Network of Biosphere Reserves. Available online: https://en.unesco. org/biosphere/wnbr (accessed on 10 May 2020).

15. UNESCO. MAB Strategy 2015-2025; UNESCO, Man and the Biosphere Programme: Paris, France, 2015.

16. Coetzer, K.L.; Witkowski, E.T.F; Erasmus, B.F.N. Reviewing Biosphere Reserves globally: Effective conservation action or bureaucratic label? Biol. Rev. Camb. Philos. Soc. 2014, 89, 82-104. [CrossRef] [PubMed]

17. UNESCO. A New Roadmap for the Man and the Biosphere (MAB) Programme and Its World Network of Biosphere Reserves. MAB Strategy (2015-2025), Lima Action Plan (2016-2025), Lima Declaration; UNESCO: Paris, France, 2017.

18. UNESCO. What Are Biosphere Reserves? Available online: https://en.unesco.org/biosphere/about (accessed on 10 May 2020). 
19. Price, M.F.; Park, J.J.; Bouamrane, M. Reporting progress on internationally designated sites: The periodic review of biosphere reserves. Environ. Sci. Policy 2010, 13, 549-557. [CrossRef]

20. UNESCO. Biosphere Reserves: The Seville Strategy and the Statutory Framework of the World Network; UNESCO: Paris, France, 1996.

21. German MAB National Committee. Full of Life. UNESCO Biosphere Reserves-Model Regions for Sustainable Development; Springer: Berlin/Heidelberg, Germany, 2005.

22. Makenzi, P.M. The Biosphere Reserve Concept as a Tool for Sustainable Natural Resource Management in the Eastern Africa Region. In AfriMAB. Biosphere Reserves in Sub-Saharan Africa: Showcasing Sustainable Development; Pool-Stanvliet, R., Clüsener-Godt, M., Eds.; UNESCO: Paris, France, 2013.

23. van Cuong, C.; Dart, P.; Hockings, M. Biosphere reserves: Attributes for success. J. Environ. Manag. 2017, 188, 9-17. [CrossRef] [PubMed]

24. Nautiyal, S.; Maikhuri, R.K.; Rao, K.S.; Saxena, K.G. Medicinal Plant Resources in Nanda Devi Biosphere Reserve in the Central Himalayas. J. Herbs Spices Med. Plants 2001, 8, 47-64. [CrossRef]

25. Carius, F. Tourism Revenue Sharing with Local Communities: A Case Study of Jozani-Chwaka Bay National Park and Biosphere Reserve, Zanzibar; University of Kaiserslautern: Kaiserslautern, Germany, 2016.

26. German Commission for UNESCO. For Life, for the Future. Biosphere Reserves and Climate Change. A Collection of Good Practice Case Studies; German Commission for UNESCO: Bonn, Germany, 2011.

27. Chape, S.; Spalding, M.; Jenkins, M. The World's Protected Areas. Status, Values and Prospects in the 21st Century; UNEP-WCMC and University of California: Berkely, CA, USA, 2008.

28. Makenzi, P.M. Foreword. In AfriMAB. Biosphere Reserves in Sub-Saharan Africa: Showcasing Sustainable Development; Pool-Stanvliet, R., Clüsener-Godt, M., Eds.; UNESCO: Paris, France, 2013.

29. UNESCO. International Co-Ordinating Council of the Man and the Biosphere (MAB) Programme. 31st Session. Final Report, 2019. Available online: https:/unesdoc.unesco.org/ark:/48223/pf0000370193 (accessed on 10 May 2020).

30. Anonymous. Exploring the potential and contribution of UNESCO Biosphere Reserves for landscape governance and management in Africa: Lake Bosomtwe Biosphere Reserve, Ghana. Semi-Structured Expert Interview (via telephone), 6 April 2020.

31. Anonymous. Exploring the potential and contribution of UNESCO Biosphere Reserves for landscape governance and management in Africa: Vhembe Biosphere Reserve, South Africa. Personal Semi-Structured Expert Interview, 13 February 2020.

32. Alpert, P. Integrated Conservation and Development Projects. BioScience 1996, 46, 845-855. [CrossRef]

33. Newman, E.D.; Hough, J.L. Conserving Wildlife in Africa: Integrated Conservation and Development Projects and beyond. BioScience 2000, 50, 585-592.

34. Roe, D.; Nelson, F.; Sandbrook, C. Community Management of Natural Resources in Africa: Impacts, Experiences and Future Directions; Natural Resource Issues No. 18; International Institute for Environment and Development: London, UK, 2009.

35. Torri, M.C. Conservation, Relocation and the Social Consequences of Conservation Policies in Protected Areas: Case Study of the Sariska Tiger Reserve, India. Conserv. Soc. 2011, 9, 54-64. [CrossRef]

36. Chevallier, R. The State of Community-Based Natural Resource Management in Southern Africa: Assessing Progress and Looking Ahead; SAIIA Occasional Paper No. 240; South African Institute of International Affairs: Johannesburg, South Africa, 2016.

37. Politicians and Poachers. Available online: https://books.google.de/books?hl=de\&lr=\&id=kmD-P9LlrEC\&oi=fnd\&pg=PR11\&dq=Africa + previous + conservation + approaches,+ focusing + primarily + on + the+establishment+of+protected+areas, +had+been+ineffective+in+stopping+general+habitat+loss+ and+the+poaching+of+protected+species.\&ots=Lyb5dMvvnM\&sig=M8_iRFE8SBkwEOa9JjvxCg-J1ZQ\& redir_esc $=\mathrm{y} \# \mathrm{v}=$ onepage \&q\&f$=$ false (accessed on 18 June 2020).

38. Barrett, C.B.; Arcese, P. Are Integrated Conservation-Development Projects (ICDPs) Sustainable? On the conservation of large mammals in sub-Saharan Africa. World Dev. 1995, 23, 1073-1084. [CrossRef]

39. Frost, P.G.H.; Bond, I. The CAMPFIRE program in Zimbabwe: Payments for wildlife services. Ecol. Econ. 2008, 65, 776-787. [CrossRef] 
40. Dyer, J.; Stringer, L.C.; Dougill, A.J.; Leventon, J.; Nshimbi, M.; Chama, F.; Kafwifwi, A.; Muledi, J.I.; Kaumbu, J.-M.K.; Falcao, M.; et al. Assessing participatory practices in community-based natural resource management: Experiences in community engagement from southern Africa. J. Environ. Manag. 2014, 137, 137-145. [CrossRef] [PubMed]

41. Kozak, R.; Buck, L.E.; Barrow, E.G.; Sunderland, T.C.H.; Catacutan, D.E.; Planicka, C.; Hart, A.K.; Willemen, L. Toward Viable Lanndscape Governance Systems. What Works? 2014. Available online: http://www.cifor.org/ knowledge/publication/4814/ (accessed on 10 May 2020).

42. Ros-Tonen, M.; Derkyi, M.; Insaidoo, T.F.G. From Co-Management to Landscape Governance: Whither Ghana's Modified Taungya System? Forests 2014, 5, 2996-3021. [CrossRef]

43. UNEP. Report on How to Improve Sustainable Use of Biodiversity in a Landscape Perspective. Executive Summary. UNEP/CBD/SBSTTA/14/13, 2011. Available online: https://www.cbd.int/doc/meetings/sbstta/ sbstta-15/official/sbstta-15-13-en.pdf (accessed on 15 May 2020).

44. Battisti, C. Why is it so difficult to have success? Applying the Swiss Cheese theory to environmental practices. Environ. Pr. 2018, 20, 42-54. [CrossRef]

45. Adams, W.C. Conducting Semi-Structured Interviews. In Handbook of Practical Program Evaluation, 4th ed.; Hatry, H.P., Wholey, J.S., Newcomer, K.E., Eds.; Jossey-Bass a Wiley Imprint: San Francisco, CA, USA, 2015; pp. 492-505, ISBN 9781119171386.

46. UNESCO. Ecological Sciences for Sustainable Development-Man and the Biosphere (MAB) Programme. Available online: http://www.unesco.org/new/en/natural-sciences/environment/ecologicalsciences/biosphere-reserves/africa/ (accessed on 24 April 2020).

47. Department for Environmental Affairs, Republic of South Africa. The South African Strategy for the Biosphere Reserve Programme (2016-2020). 2016. Available online: https://www.environment.gov.za/sites/ default/files/reports/southafricanstrategy_biospherereserve2016_2020.pdf (accessed on 10 May 2020).

48. Vhembe Biosphere Reserve. Structure of the VBR and Partners. Available online: https://www. vhembebiosphere.org/about-vbr/structure-of-the-vbr-and-partners (accessed on 10 May 2020).

49. LEDET. Vhembe District Bioregional Plan. Limpopo Department of Economic Development, Environment and Tourism. Available online: http://www.nuleafsa.co.za/wp-content/uploads/2018/01/Vhembe-BioregionalPlan_rev4_Dec-2017_name-changes.pdf/ (accessed on 23 April 2020).

50. Vhembe Biosphere Reserve. Constitution of the Vhembe Biosphere Reserve. Available online: https://www. vhembebiosphere.org/wp-content/uploads/2018/03/VBR_Membership_Form_March_2018.docx/(accessed on 7 May 2020).

51. IUCN. Upscaling Community Resource Management Areas as a Delivery Mechanism for REDD+ Implementation in Ghana. Brief, 2017. Available online: https://www.iucn.org/sites/dev/files/content/ documents/upscaling_community_resource_management_-_ghana.pdf (accessed on 7 May 2020).

52. Anonymous. Exploring the potential and contribution of UNESCO Biosphere Reserves for landscape governance and management in Africa: Mount Mulanje Biosphere Reserve, Malawi. Semi-Structured Expert Interview (via telephone), 9 March 2020.

53. Anonymous. Exploring the potential and contribution of UNESCO Biosphere Reserves for landscape governance and management in Africa: Mono Biosphere Reserve, Benin/Togo. Semi-Structured Expert Interview (via telephone), 17 March 2020.

54. Stoll-Kleemann, S.; Dela Vega-Leinert, A.C.; Schultz, L. The role of community participation in the effectiveness of UNESCO Biosphere Reserve management: Evidence and reflections from two parallel global surveys. Environ. Conserv. 2010, 37, 227-238. [CrossRef]

55. German Commission for UNESCO. Management Manual for UNESCO Biosphere Reserves in Africa; German Commission for UNESCO: Bonn, Germany, 2015.

56. Deldicque, M. Dialogue in the itinerary of biosphere reserve creation. In Dialogue in Biosphere Reserves: References, Practices and Experiences; Bouamrane, M., Ed.; UNESCO, Man and Biosphere Programme: Paris. France, 2008; pp. 5-22.

57. Pool-Stanvliet, R.; Stoll-Kleemann, S.; Giliomee, J.H. Criteria for selection and evaluation of biosphere reserves in support of the UNESCO MAB programme in South Africa. Land Use Policy 2018, 76, 654-663. [CrossRef] 
58. Bennet, G.; Mulongoy, K.J. Review of Experience with Ecological Networks, Corridors and Buffer Zones; CBD Technical Series No. 23; 2006. Available online: https://www.cbd.int/doc/publications/cbd-ts-23.pdf (accessed on 10 May 2020).

59. BRRhoen. UNESCO-Biosphärenreservat Rhön-Mediendienst aus Bayern, Hessen und Thüringen. Available online: https://www.inter-research.de/documents/BRRhoen_03_2008.pdf/ (accessed on 25 April 2020).

60. Departement of Trade and Industry. Designation of the Musina- Makhado Special Economic Zone (South African Energy and Metallurgical Zone). Available online: https://www.gov.za/sites/default/files/gcis_ document/201712/41287gon1324.pdf/ (accessed on 17 March 2020).

61. Linstädter, A. Understanding and communicating the delivery of ecosystem services in African biosphere reserves -examples from South Africa. In Proceedings of the Workshop "UNESCO Biosphere Reservesin Africa-Research Meets Development for the Implementation of the Global Sustainability Agenda 2030", Paris, France, 12-15 June 2017.

62. Rozylowicz, L.; Nita, A.; Manolache, S.; Popescu, V.D.; Hartel, T. Navigating protected areas networks for improving diffusion of conservation practices. J. Environ. Manag. 2019, 230, 413-421. [CrossRef]

63. Nita, A. Empowering impact assessments knowledge and international research collaboration: A bibliometric analysis of Environmental Impact Assessment Review journal. Environ. Impact Assess. Rev. 2019, 78, 106283. [CrossRef]

64. Reed, M.G.; Abernethy, P. Facilitating Co-Production of Transdisciplinary Knowledge for Sustainability: Working with Canadian Biosphere Reserve Practitioners. Soc. Natur. Resour. 2018, 31, 39-56. [CrossRef]

65. Mose, I.; McDonald, P.A. Protected Areas and Regional Development in Europe: Towards a New Model for the 21st Century; Ashgate Publishing Limited: Farnham, UK, 2012.

66. Mbow, C.; Neely, C.; Dobie, P. How Can an Integrated Landscape Approach Contribute to the Implementation of the Sustainable Development Goals (SDGs) and Advance Climate-Smart Objectives? Minang, P.A., van Noordwijk, M., Freeman, O.E., Mbow, C., de Leeuw, J., Catacutan, D., Eds.; World Agroforestry Centre: Nairobi, Kenya, 2015.

67. Jacobson, S.K.; McDuff, M.D.; Monroe, M.C. Conservation Education and Outreach Techniques, 2nd ed.; Oxford University Press: Oxford, UK, 2015; ISBN 9780198716693.

(C) 2020 by the authors. Licensee MDPI, Basel, Switzerland. This article is an open access article distributed under the terms and conditions of the Creative Commons Attribution (CC BY) license (http://creativecommons.org/licenses/by/4.0/). 